\title{
Consumers' Willingness to Choose a National Payment Card: A Stated Preference Approach
}

\author{
U. Attanayake ${ }^{1} \&$ P. Neelawala ${ }^{2}$ \\ London Metropolitan University-UK and ESOFT Metro Campus, \\ Kandy ${ }^{1}$, ESOFT Metro Campus, Kandy ${ }^{2}$ \\ upul.attanayake@gmail.com ${ }^{1}$, prasad5700@gmail.com ${ }^{2}$
}

Received: 27 January 2020

Accepted: 28 October 2020

\begin{abstract}
This study is to identify the consumers' willingness to choose a national payment card and to assess how it can compete with the existing International Payment Networks in the domestic banking market, commissioning conjoint analysis. The research investigates whether the current mechanism adopted by Sri Lanka meets these requirements. Furthermore, the strategic movement by Sri Lanka towards achieving this target is critically analyzed with opportunities for improvement that are meant to be beneficial for the country. The sample size for the study was 81 , and the response rate was $53.29 \%$. The profiles were generated by applying orthogonal design. The analytical model for the study was the Rank Ordered Logit model. The research has shown that out of nine hypotheses, three were three significant variables which are Option, Dispute Management, and Card Industry Standard and having the impacts of -0.58 (58\%), -0.29 (29\%), and 0.29 (29\%) respectively on willingness to choose.

Keywords: Conjoint Analysis, Payment Card, Rank Ordered Logit Model
\end{abstract}




\section{Introduction}

Consumers are complex entities whose behaviour is closely linked to a set of socio-demographic and psychographic factors as well as cultural aspects. Presently, many customers choose to make payments by card as it is more convenient and secure. When choosing a payment card brand, they opt for well-known brands such as VISA, Master, and AMEX as they are internationally well established and trusted by many. They also offer many benefits such as special discount schemes through their large network of reputed vendors and service providers. It is in this highly competitive climate that Sri Lanka is proposing to introduce a national card brand.

Soman $(2001,2003)$ found that the use of prepaid cards (integrated circuit cards, ICC, usually referred to as 'smart cards') increases the amount spent per transaction. However, because the money is transferred so it can be used for a specific purpose, there may be an awareness that the money is 'spent'. Hence, this research tries to ascertain the success of a proposed local payment card brand by examining the mindset of potential customers.

As a mover to diversify the payment card operations in Sri Lanka, proposed to launch Sri Lanka's very own National Card Scheme (NCS) to Sri Lankan customers. There are several international payment card brands currently operating in Sri Lanka, and there are no local brands currently operating in this field. Therefore the need for a national brand is strongly felt.

Sri Lanka is a country which is having an increasing demand for international payment cards. They are mainly VISA and Master Cards. However, there is a potential niche market for a national payment card scheme. Further, the policymakers of the financial sector have mixed opinions over the factors impacting customers' choice of a national payment card. Therefore the main objective of this study is to identify the consumers' willingness to choose a national payment card and to assess how it can compete with the existing International Payment Networks in the domestic banking market, commissioning conjoint analysis. The main research question 
in this study is delineating the key attributes of a payment card which determines the consumers' choice.

\section{Literature Review}

\subsection{Overview of Payment Card Attributes}

In order to identify the main areas of interest in this study, the researcher has perused the relevant literature in areas such as conjoint analysis, payment cards, and benefits of holding payment cards. Many past researchers have examined the viability of credit cards and debit cards in various other countries. Their findings are well documented, preserved, and available for perusal. Therefore, a vast amount of research literature exists in this area. However, in the Sri Lankan context, the availability of the literature is significantly less due to the fact that little research has been conducted locally on this subject. Nevertheless, this researcher has managed to accumulate an adequate amount of information to conduct a valid and rational study on the use of a national payment card.

In the reported literature, the interest rate and benefits are highlighted as essential characteristics. At the same token, it is evident that the average interest rates of credit cards in Sri Lanka are significantly high compared to the "going rate" of lending by commercial banks. Further, there are certain monetary rewards from different service providers that make a precise segmentation in the credit card markets $(50 \%$ discounts, Rewarding for loyal customers). The moral sentiments of the national identity of the users are one of the key characteristics of getting attracted to certain products. In that scenario, credit cards too are not an exemption as studied by (Huang, 2005). (Huang, 2005) have expressly provided evidence to support the affiliation of the national identity of choosing credit cards using the example of UnionPay and RuPay.

Furthermore, the security standard of the payment cards is playing a critical role in choosing a payment card by customers. When discussing financial handling and in terms of accessing a potentially large amount of 'virtual' money, a high degree of security is 
important (Mann, 2002). In addition to security standards, the international reputation of a product will bring the customer choice into another stage. The operation of the world's most advanced processing networks which facilitates authorization, clearing and settlement of payment transactions worldwide are highly essential (Visa, 2018). Further to the international reputation, the dispute management of a payment card network is highly important in customer convenience. In order to get a convenient service, the Customer should notify the issues or errors to the card centre immediately or within a short period of days from the statement date (HNB, 2018). Apart from all above-mentioned attributes, the industry standards required for a payment card network is highly important. The whole purpose of the standards like Payment Card Industry Data Security Standard (PCI-DSS) is to protect card data from hackers and thieves. By following this standard, the entity can keep the data secure, avoiding costly data breaches, and protecting the employees and customer base. Therefore, the researcher has added card industry standards to the analytical framework in order to check the significance of the particular variable (Securitymetrics, 2016).

As per Simon et al. (2010) use transaction-level information to evaluate that, after holding dealer type, size of exchange and segment attributes steady, the nearness of loyalty or prizes expanded the likelihood of the Visa utilized for a given exchange by 23 rates focuses, while access to a premium-free period expanded the likelihood by 16 rate focuses. According to Rutherford and DeVaney (2009), the research efforts went beyond identifying who uses credit cards to look at how the possession of these cards influences purchasing behaviour. Borzekowski et al. (2006) report that several studies in the US that use various versions of the Survey of Consumer Finances (SCF) all show that debit card users are younger, well-educated and more likely to be female. When considering the age limits, as described by Hayashi (2010), one possibility is that the effect is generational: the high credit card users are the post-war Baby Boom generation, whose experience with the 
great depression was sufficiently remote to make casual use of credit tolerable.

According to Hirschman (1979), differences in consumer purchase behavior are based on credit card characteristics interest rates, and benefits. Lam and Ossolinski (2015) estimate consumers' willingness to pay a surcharge to use their card, as a measure of the consumer surplus from card use. However the research found that cards fluctuate in their annual charges, interest rates, the liberality of their prizes program, the interest free days they offer, and the size of specially appointed expenses - for example, late installment charges (Brainard, 2017). Supporters face monetary motivating forces to hold and use Visas, for example, rewards programs or an interest free period, and those are depicted in Simon, et al. (2010), Doyle (2018) and Lam and Ossolinski (2015). At the hour of picking their card, cardholders do not hope to cause intrigue charges (for example by thinking little of their likely spending or overestimating their future pay and capacity to reimburse), the loan cost is probably not going to factor into their choice, and they may pick a high-rate payment card. On the off chance that that desire ends up being a deliberate underestimation, these customers will confront substantially higher interest charges than if they had picked a lowerrate card (Markoczy et al., 2007). Proof of present inclination in reacting to charge card join offers has been found in the US market. In an examination, the credit card issuer with fluctuating early on financing cost offers to 600,000 purchasers (Shui and Ausubel, 2005). Further, As indicated by Fusaro (2013), clients of debit cards will, in general, be obligation disinclined.

When considering Annual Fee, Radhakrishan (1996) study on debit cards shows that the debit cards also have found wide acceptability than credit cards because of assurance of payments to retailers, switching of cardholders to debit card because of using the interestfree period to avoid the high-interest cost, annual charges as compared to debit cards. According to Churchill and Surprenant (1982), customer satisfaction is a comparison of the rewards and costs associated with the use or purchase of a good or service concerning the anticipated consequences of the use or purchase. 
They compared customer satisfaction to an attitude. Some evidence suggests that using a credit card can lead consumers to grow their total expenditure. This effect may be driven by alleviation of liquidity constraints, or by behavioural aspects (Thomas, Desai and Seenivasan 2011; Chatterjee and Rose 2012).

National Pride for a product is highly important. As per Sarika and Vasantha (2019) RuPay, a new card payment scheme launched by the National Payments Corporation of India (NPCI), has been regarded to fulfil Reserve Bank of India (RBI)'s vision to offer a domestic, open-loop, multilateral system which will allow all Indian banks and financial organizations in India to contribute in electronic payments. UnionPay is a bankcard association established under the approval of the State Council and the People's Bank of China. At present, the Shanghai-headquartered UnionPay has about 400 domestic and overseas associate members (Prange, 2016). Similar to National pride, the card should carry an international reputation, and example for the same as; Visa Inc. is a global payment technology organization that interfaces customers, organizations, financial organizations, and governments over 200 nations and regions to quick, secure, and reliable electronic instalments. They operate one of the world's most advanced processing networks - VisaNet which facilitates authorization, clearing and settlement of payment transactions worldwide (Visa, 2018).

The cardholder shall look at the statement of account and any blunder in that ought to be informed the card issuer within 15 days from the dispute. The Bank will require the Cardholder's Name, Payment Card No, Transaction Date, and the Transaction Amount to examine the issue (HNB, 2018). In consideration of pecuniary transactions, the credit card has become an effective system of payments that stimulates household and personal spending, even in many developing countries of the world (Watkins, 2000). According to Mann (2002), debit and credit cards share similar characteristics in terms of accessing a potentially large amount of 'virtual' money with a high degree of security. 
It is very much important to protect the data of the business, clients, and employees. While paying attention to the physical security in the business, it is equally important to protect the digital information as well. Between malware threats, remote-access attacks, and social engineering, it's important to take the proper precautions to keep personal computers, networks, and servers security to maintain the standards. The whole purpose of the certification like PCI-DSS is to protect card data from hackers and thieves. By following this standard, the entity can keep the data secure, avoiding costly data breaches, and protecting the employees and customer base (Securitymetrics, 2016).

\subsection{Application of Conjoint Analysis}

According to Raghavarao et al. (2010), conjoint analysis is applied in situations where the choice made by a person on a particular product/service depends on many attributes of a product or service. These attributes have levels or part-worth components while described in the SAGE web site, as the conjoint analysis is a marketing technique for predicting how a new product would perform when introduced to the market (Sagepub, 2018).

As per Leeper et al. (2020), we can identify Conjoint analysis as a generic way to identify preferences. This method disperses a good pattern of respondents to complex and different dimensional stuff such as candidates or politicians. The most conjoint analyses rely on a completely random design to produce average marginal component effects which measure the degree to which a given value of the conjoint profile characteristic, by averaging all respondents and other characteristics, increases or decreases defendants' support for the overall profile pertaining to baseline. At the same time, average marginal component effects have a clear on the influence of characteristics. Further, most produced conjoint analyses also use a fully randomized design to describe choice levels. It further explains the conjoint output always comparing average marginal component effects to subgroups of respondents. 


\section{Methodology}

The methodological choice of the paper is dependent on the consumers' willingness to choose the payment card. Therefore, it is a naturally discrete choice. Hence, the conjoint analysis, as it has been justified in the literature review, was selected as the analytical framework. It allows the researcher to accommodate the preferences of the payment card users concerning their attributes. Especially in this research, a card which is not introduced to the market is tested with the available payment cards. Therefore, the conjoint analysis provides the space to make independent choices by the respondents. The orthogonal design, which has been carried out, let the researcher decide the most rational choices for the consumers. The data were collected from pre-identified existing payment card customers as well as potential customers. The respondents were selected using a convenience sampling method which led to identifying the most effective customer base. There were 81 responses which reflected $53.29 \%$ of the response rate, and it is a significant rate as far as the average response rate (around 20\%) for an online survey. The questionnaires were pre-tested, and pilot tested using selected respondents from the existing sample. Questions of this choice based survey were for capturing demographic information, namely area of living, age, profession, marital status, and gender. Also, the survey has obtained information related to the number of payment cards, existing brands they are using. Three supplementary documents, namely covering letter, consent letter, and an information sheet were included in the online survey, and it guaranteed the participant about research ethics, and ensure complete awareness of the participant on this study, the possible future impacts of taking part in this survey, and privacy and confidentiality of the data they provided. Hence, there was not any researcher's influence on the participant's choice. The finalized questionnaire was distributed using Google forms to the respondents in Central, Western, Sabaragamuwa, North Central, and Eastern provinces. The collected data were coded and used to run the Rank Ordered Logit model.

Table 1 shows the four combinations and their attributes level from top to bottom. There are nine attributes for four choices. The 
number of choices is calculated based on the full factorial design. The full factorial design is based on the available attributes and levels. The number of possible profiles is $a^{n}$ where $a$ is the number of levels and $n$ is the number of attributes. If there are different levels for the attributes, then $a^{n} \times b^{m}$ solves for the case as $a$ and $b$ are levels, and $m$ and $n$ are attributes (Tinelli, 2016). Accordingly, in this research, there are 96 possible choices. However, for the final research implementation, four rational choices were used depending on the market information, in the choice experiment.

Table 1: Choice Set Model

\begin{tabular}{|c|c|c|c|c|}
\hline FEATURES & $\begin{array}{c}\text { Payment } \\
\text { Card A }\end{array}$ & $\begin{array}{c}\text { Payment } \\
\text { Card B }\end{array}$ & $\begin{array}{c}\text { Payment } \\
\text { Card C }\end{array}$ & $\begin{array}{c}\text { Payment } \\
\text { Card D }\end{array}$ \\
\hline Annual Fee & 2600LKR & 2250LKR & $\begin{array}{c}5700 \mathrm{LK} \\
\mathrm{R}\end{array}$ & $\begin{array}{l}\text { Free of } \\
\text { Charge }\end{array}$ \\
\hline $\begin{array}{l}\text { Package } \\
\text { Benefits }\end{array}$ & $\begin{array}{c}\text { Complimen } \\
\text { tary } \\
\text { Travel } \\
\text { Insurance }\end{array}$ & $\begin{array}{c}\text { Complimen } \\
\text { tary } \\
\text { Travel } \\
\text { Insurance }\end{array}$ & $\begin{array}{c}\text { Complim } \\
\text { entary } \\
\text { Travel } \\
\text { Insurance }\end{array}$ & $\begin{array}{c}\text { Complimenta } \\
\text { ry } \\
\text { Travel } \\
\text { Insurance }\end{array}$ \\
\hline $\begin{array}{c}\text { Minimum } \\
\text { Transaction } \\
\text { Requirements }\end{array}$ & Yes & Yes & Yes & No \\
\hline National Pride & No & No & No & Yes \\
\hline $\begin{array}{l}\text { International } \\
\text { Reputation }\end{array}$ & $\begin{array}{l}\text { Can be } \\
\text { used in } \\
\text { any } \\
\text { Country }\end{array}$ & $\begin{array}{l}\text { Can be } \\
\text { used in } \\
\text { any } \\
\text { Country }\end{array}$ & $\begin{array}{c}\text { Can be } \\
\text { used in } \\
\text { any } \\
\text { Country } \\
\end{array}$ & $\begin{array}{c}\text { Can be used } \\
\text { in } \\
\text { any Country }\end{array}$ \\
\hline $\begin{array}{c}\text { Dispute } \\
\text { Management }\end{array}$ & $\begin{array}{l}\text { Internation } \\
\text { al Rules }\end{array}$ & $\begin{array}{l}\text { Internation } \\
\text { al Rules }\end{array}$ & $\begin{array}{c}\text { No } \\
\text { proper } \\
\text { laid rules }\end{array}$ & $\begin{array}{c}\text { Localized } \\
\text { rules to meet } \\
\text { domestic } \\
\text { needs }\end{array}$ \\
\hline EMV Chip & Yes & Yes & No & Yes \\
\hline $\begin{array}{l}\text { Card Industry } \\
\text { Standard }\end{array}$ & PCI-DSS & PCI-DSS & $\begin{array}{c}\text { No any } \\
\text { card } \\
\text { industry } \\
\text { standards }\end{array}$ & PCI-DSS \\
\hline Value Additions & $\begin{array}{l}\text { Contact } \\
\text { Less card }\end{array}$ & $\begin{array}{l}\text { Contact } \\
\text { Less card }\end{array}$ & $\begin{array}{l}\text { Contact } \\
\text { Less card }\end{array}$ & $\begin{array}{l}\text { 1. Contact } \\
\text { Less card } \\
\text { 2.Usability as } \\
\text { a Top-up } \\
\text { card }\end{array}$ \\
\hline
\end{tabular}

Source: Survey Data 


\subsection{Data Collection}

Primary data were collected using a choice experiment survey employing a conjoint analysis. Finally, the purified data are taken and analyzed using tables, graphs, and charts with the support of the SPSS Statistics software package, to derive observations and conclusions.

The target population is the credit users of the five different districts, and sampling process is based on the convenience sampling. There were 81 responses were received and response rate is $53.29 \%$.

\subsection{Theoretical and Functional Model of the Conjoint Analysis}

Choices consist of nine attributes and several levels for each attribute. The alternative choices have been made using the method of Orthogonal Design. The following full-factorial solution is used to develop the choices.

$$
U_{i m}=1-L_{i} \frac{\sum_{n=1}^{L_{j}} \beta R_{\text {imjm }}}{\sum_{n=1}^{L_{j}} \beta \sum_{m=1}^{L_{i}} R_{i m j n}}
$$

Where:

$U_{i m}$ - the estimated utility value of level $m$ of attribute $i$ and $R_{i m j n}$ - the rankings for level $m$ of attribute $i$ and level $n$ of attribute $j$

The functional form of the Rank order logit model is given below (Kuzmanovic, 2011).

$$
y_{i}=\alpha+\beta_{1} X_{1 j}+\beta_{2} X_{2 j}+\cdots \ldots \ldots+\beta_{m} X_{m j}+\varepsilon_{j}
$$

for $j=\{1, \ldots, n\}$, where $X_{i j}$ are independent variables. In matrix notation, Equation 1 can be written as $\mathbf{y}=\alpha+\beta \mathbf{X}+\boldsymbol{e}$, where $\mathbf{X}$ is the orthogonally coded design matrix of independent variables.

\section{Analysis}

The data analysis was conducted as a choice based experiment. The dependent variable is the consumers' willingness to choose a Peradeniya Management Review - Volume II Issue 1 (June) 2020 
particular payment card. The independent variables are Annual Fee (AF), Package Benefits (PB), Minimum Transaction Requirements (MTR), National Pride (NP), International Reputation (IR), Dispute Management (DP), EMV Chip (EMV), Card Industry Standard (CIS) and Value Additions (VA). The Option variable defines the consumers' tendency to move from the chosen card to the next best alternative.

Table 2 shows the distributional characteristics of all the variables used for the research. The standard deviation is comparatively low value. It is a good sign of central tendency. Also, Skewness and Kurtosis values are within the desirable range, between +3 and -3 for Skewness and +2 and -2 for the Kurtosis.

Table 2: Descriptive Statistics

\begin{tabular}{|c|c|c|c|c|c|c|}
\hline $\begin{array}{c}\text { Variable } \\
\text { Name }\end{array}$ & $\begin{array}{c}\text { Mini } \\
\text { mum }\end{array}$ & $\begin{array}{c}\text { Maxi } \\
\text { mum }\end{array}$ & Mean & $\begin{array}{c}\text { Std. } \\
\text { Deviation }\end{array}$ & Skewness & $\begin{array}{c}\text { Kurtos } \\
\text { is }\end{array}$ \\
\hline Choice & 1.00 & 4.00 & 2.51 & 1.11 & -0.02 & -1.35 \\
\hline Option & 1.00 & 4.00 & 2.50 & 1.12 & 0.00 & -1.36 \\
\hline AF & 0.00 & $\begin{array}{c}5700 . \\
00\end{array}$ & $\begin{array}{c}2675 . \\
31\end{array}$ & 2048.94 & 0.28 & -1.04 \\
\hline MTR & 0.00 & 1.00 & 0.75 & 0.43 & -1.18 & -0.61 \\
\hline NP & 0.00 & 1.00 & 0.25 & 0.43 & 1.18 & -0.61 \\
\hline IR & 0.00 & 1.00 & 0.75 & 0.43 & -1.18 & -0.61 \\
\hline DM & 0.00 & 3.00 & 1.98 & 1.24 & -0.78 & -1.08 \\
\hline EMV & 0.00 & 1.00 & 0.74 & 0.44 & -1.10 & -0.79 \\
\hline CIS & 0.00 & 1.00 & 0.74 & 0.44 & -1.10 & -0.79 \\
\hline VA & 1.00 & 2.00 & 1.25 & 0.43 & 1.18 & -0.61 \\
\hline
\end{tabular}

Source: Survey Data

Table 3 shows the Pearson correlation statistics for all the variables used in the analysis. The majority of the significant combinations of correlations have values which are mild and moderate. Few combinations are having high correlations (above 0.7). 
Table 3: Correlational Analysis

\begin{tabular}{|c|c|c|c|c|c|c|c|c|c|c|}
\hline & $\frac{\stackrel{\mathscr{U}}{e}}{\stackrel{\Xi}{U}}$ & 氖 & $\frac{1}{4}$ & $\underline{\underline{E}}$ & $\hat{\mathbf{z}}$ & $\underline{\underline{a}}$ & 主 & $\sum_{i=1}^{Z}$ & $\stackrel{\mathscr{\Omega}}{\circlearrowright}$ & 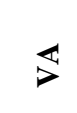 \\
\hline \multirow{2}{*}{$\frac{\ddot{U}}{0}$} & 1 & $\begin{array}{l}-.479 \\
* *\end{array}$ & $\begin{array}{l}-.228 \\
* *\end{array}$ & $\begin{array}{l}-.769 \\
* *\end{array}$ & $\begin{array}{l}.769 \\
* *\end{array}$ & $\begin{array}{l}-.769 \\
* *\end{array}$ & $\begin{array}{l}-.547 \\
* *\end{array}$ & $\begin{array}{l}-.263 \\
* *\end{array}$ & $\begin{array}{l}-.263 \\
* *\end{array}$ & $\begin{array}{l}.769 \\
* *\end{array}$ \\
\hline & & .000 & .000 & .000 & .000 & .000 & .000 & .000 & .000 & .000 \\
\hline \multirow{2}{*}{ 苛 } & $\begin{array}{c}-.479 \\
* *\end{array}$ & 1 & $\begin{array}{l}.495 \\
* *\end{array}$ & $\begin{array}{l}.640 \\
* *\end{array}$ & $\begin{array}{l}-.640 \\
* *\end{array}$ & $\begin{array}{l}.640 \\
* *\end{array}$ & -.031 & $\begin{array}{l}-.239 \\
* *\end{array}$ & $\begin{array}{l}-.239 \\
* *\end{array}$ & $\begin{array}{l}-.640 \\
* *\end{array}$ \\
\hline & .000 & & .000 & .000 & .000 & .000 & .575 & .000 & .000 & .000 \\
\hline \multirow{2}{*}{ 岁 } & $\begin{array}{c}-.228 \\
* *\end{array}$ & $\begin{array}{l}.495 \\
* *\end{array}$ & 1 & $\begin{array}{l}.749 \\
* *\end{array}$ & $\begin{array}{l}-.749 \\
* *\end{array}$ & $\begin{array}{l}.749 \\
* *\end{array}$ & $\begin{array}{l}-.669 \\
* *\end{array}$ & $\begin{array}{l}-.875 \\
* *\end{array}$ & $\begin{array}{l}-.875 \\
* *\end{array}$ & $\begin{array}{l}-.749 \\
* *\end{array}$ \\
\hline & .000 & .000 & & .000 & .000 & .000 & .000 & .000 & .000 & .000 \\
\hline \multirow{2}{*}{$\stackrel{n}{\Sigma}$} & $\begin{array}{c}-.769 \\
* *\end{array}$ & $\begin{array}{l}.640 \\
* *\end{array}$ & $\begin{array}{l}.749 \\
* *\end{array}$ & 1 & $\begin{array}{l}-1.000 \\
* *\end{array}$ & $\begin{array}{l}1.000 \\
* *\end{array}$ & -.011 & $\begin{array}{l}-.339 \\
* *\end{array}$ & $\begin{array}{l}-.339 \\
* *\end{array}$ & $\begin{array}{l}-1.00 \\
* *\end{array}$ \\
\hline & .000 & .000 & .000 & & 0.000 & 0.000 & .838 & .000 & .000 & $\begin{array}{l}0.00 \\
0\end{array}$ \\
\hline \multirow{2}{*}{ 豆 } & $\begin{array}{c}.769 \\
* *\end{array}$ & $\begin{array}{l}-.640 \\
* *\end{array}$ & $\begin{array}{l}-.749 \\
* *\end{array}$ & $\begin{array}{l}-1.000 \\
* *\end{array}$ & 1 & $\begin{array}{l}-1.000 \\
* *\end{array}$ & .011 & $\begin{array}{l}.339 \\
* *\end{array}$ & $\begin{array}{l}339 \\
* *\end{array}$ & $\begin{array}{l}1.00 \\
0^{* * *}\end{array}$ \\
\hline & .000 & .000 & .000 & 0.000 & & 0.000 & .838 & .000 & .000 & 0.00 \\
\hline \multirow[t]{2}{*}{ 刍 } & $\begin{array}{c}-.769 \\
* *\end{array}$ & $\begin{array}{l}.640 \\
* *\end{array}$ & $\begin{array}{l}.749 \\
* *\end{array}$ & $\begin{array}{l}1.000 \\
* *\end{array}$ & $\begin{array}{l}-1.000 \\
* *\end{array}$ & 1 & -.011 & $\begin{array}{l}-.339 \\
* *\end{array}$ & $\begin{array}{l}-.339 \\
* *\end{array}$ & $\begin{array}{l}-1.00 \\
* *\end{array}$ \\
\hline & .000 & .000 & .000 & 0.000 & 0.000 & & .838 & .000 & .000 & 0.00 \\
\hline \multirow{2}{*}{$\sum_{\text {方 }}$} & $\begin{array}{c}-.547 \\
* *\end{array}$ & -.031 & $\begin{array}{l}-.669 \\
* *\end{array}$ & -.011 & .011 & -.011 & 1 & $\begin{array}{l}.945 \\
* *\end{array}$ & $\begin{array}{l}.945 \\
* *\end{array}$ & .011 \\
\hline & .000 & .575 & .000 & .838 & .838 & .838 & & .000 & .000 & .838 \\
\hline \multirow{2}{*}{$\sum_{\text {II }}^{Z}$} & $\begin{array}{c}-.263 \\
* *\end{array}$ & $\begin{array}{l}-.239 \\
* *\end{array}$ & $\begin{array}{l}-.875 \\
* *\end{array}$ & $\begin{array}{l}-.339 \\
* *\end{array}$ & $\begin{array}{l}.339 \\
* *\end{array}$ & $\begin{array}{l}-.339 \\
* *\end{array}$ & $\begin{array}{l}.945 \\
* *\end{array}$ & 1 & $\begin{array}{l}1.000 \\
* *\end{array}$ & $\begin{array}{l}.339 \\
* *\end{array}$ \\
\hline & .000 & .000 & .000 & .000 & .000 & .000 & .000 & & 0.000 & .000 \\
\hline \multirow{2}{*}{$\tilde{\circlearrowright}$} & $\begin{array}{c}-.263 \\
* *\end{array}$ & $\begin{array}{l}-.239 \\
* *\end{array}$ & $\begin{array}{l}-.875 \\
* *\end{array}$ & $\begin{array}{l}-.339 \\
* *\end{array}$ & $\begin{array}{l}.339 \\
* *\end{array}$ & $\begin{array}{l}-.339 \\
* *\end{array}$ & $\begin{array}{l}.945 \\
* *\end{array}$ & $\begin{array}{l}1.000 \\
* *\end{array}$ & 1 & $\begin{array}{l}.339 \\
* *\end{array}$ \\
\hline & .000 & .000 & .000 & .000 & .000 & .000 & .000 & 0.000 & & .000 \\
\hline \multirow{2}{*}{$\underset{>}{\}$} & $\begin{array}{c}.769 \\
* *\end{array}$ & $\begin{array}{l}-.640 \\
* *\end{array}$ & $\begin{array}{l}-.749 \\
* *\end{array}$ & $\begin{array}{l}-1.000 \\
* *\end{array}$ & $\begin{array}{l}1.000 \\
* *\end{array}$ & $\begin{array}{l}-1.000 \\
* *\end{array}$ & .011 & $\begin{array}{l}.339 \\
* *\end{array}$ & $\begin{array}{l}.339 \\
* *\end{array}$ & 1 \\
\hline & .000 & .000 & .000 & 0.000 & 0.000 & 0.000 & .838 & .000 & .000 & \\
\hline
\end{tabular}

\section{Source: Survey Data}

Table 4 provides the regression output of the rank order logit model. The marginal effects are provded in the Table 5 for further clarification. There is no significant difference between the 
coefficients of Table 4 and the marginal effects in Table 5 (with the Delta Method standard errors). There are three significant variables in this research. They are OPTION, DM, and CIS. They are significant at $1 \%, 1 \%$, and $10 \%$ respectively.

Table 4: Rank Order Logit Output

\begin{tabular}{|c|c|c|c|c|c|c|}
\hline $\begin{array}{c}\text { Variable } \\
\text { Name }\end{array}$ & $\begin{array}{c}\text { Coef } \\
\cdot\end{array}$ & $\begin{array}{c}\text { Std. } \\
\text { Err. }\end{array}$ & $\mathbf{Z}$ & $\begin{array}{c}\mathbf{P}>\mid \mathbf{z} \\
\mathbf{I}\end{array}$ & $\begin{array}{c}\mathbf{9 5 \%} \\
\text { Conf }\end{array}$ & $\begin{array}{c}\cdot \\
\text { Interval }\end{array}$ \\
\hline OPTION & -0.58 & 0.09 & -6.57 & 0.00 & -0.75 & -0.40 \\
\hline AF & 0.00 & 0.00 & 0.24 & 0.81 & 0.00 & 0.00 \\
\hline MTR & 0.23 & 0.17 & 1.34 & 0.18 & -0.11 & 0.57 \\
\hline NP & 0.09 & 0.17 & 0.5 & 0.62 & -0.25 & 0.43 \\
\hline IR & -0.24 & 0.17 & -1.37 & 0.17 & -0.57 & 0.10 \\
\hline DM & -0.29 & 0.11 & -2.57 & 0.01 & -0.50 & -0.07 \\
\hline EMV & 0.09 & 0.18 & 0.52 & 0.61 & -0.26 & 0.45 \\
\hline CIS & 0.29 & 0.17 & 1.75 & 0.08 & -0.04 & 0.62 \\
\hline VA & -0.03 & 0.17 & -0.18 & 0.86 & -0.36 & 0.30 \\
\hline
\end{tabular}

Source: Survey Data

Table 5: Marginal Output

\begin{tabular}{|c|c|c|c|c|c|c|}
\hline $\begin{array}{c}\text { Variable } \\
\text { Name }\end{array}$ & \multirow{2}{*}{$\mathbf{d y} / \mathbf{x}$} & $\begin{array}{c}\text { Delta- } \\
\text { metho }\end{array}$ & $\mathbf{d}$ & \multirow{2}{*}{$\mathbf{P} \mid \mathbf{z}$} & $\begin{array}{c}\mathbf{9 5 \%} \\
\mathbf{I} \%\end{array}$ & $\begin{array}{c}\text { Interva } \\
\mathbf{l}\end{array}$ \\
\cline { 3 - 4 } & Std. Err. & $\mathbf{Z}$ & & & \\
\hline OPTION & -0.58 & 0.09 & $\mathbf{- 6 . 5 7}$ & 0.00 & -0.75 & -0.40 \\
\hline AF & 0.00 & 0.00 & 0.24 & 0.81 & 0.00 & 0.00 \\
\hline MTR & 0.23 & 0.17 & 1.34 & 0.18 & -0.11 & 0.57 \\
\hline NP & 0.09 & 0.17 & 0.5 & 0.62 & -0.25 & 0.43 \\
\hline IR & -0.24 & 0.17 & -1.37 & 0.17 & -0.57 & 0.10 \\
\hline DM & -0.29 & 0.11 & $\mathbf{- 2 . 5 7}$ & 0.01 & -0.50 & -0.07 \\
\hline EMV & 0.09 & 0.18 & 0.52 & 0.61 & -0.26 & 0.45 \\
\hline CIS & 0.29 & 0.17 & $\mathbf{1 . 7 5}$ & 0.08 & -0.04 & 0.62 \\
\hline VA & -0.03 & 0.17 & -0.18 & 0.86 & -0.36 & 0.30 \\
\hline
\end{tabular}

Source: Survey Data 


\section{Discussion}

Table 4 provides the marginal output of the Rank Ordered Logit output of Table 3 . The options variable indicated as the probability of choosing another card has decreased by a factor of $0.58(58 \%)$. It learns that the next alternative card is less preferred to the previous choice. It further explains, once the card is present, the utility of the card user is maximized regardless of the characteristic of the next best alternative. Also, when increasing the level of Dispute Management (DM) by one level, the probability of choosing the payment card will be decreased by a factor of 0.29 (29\%). It is because increase the number of disputes management represents the prevalence of disputes for a particular card. However, the CIS variable has a positive impact on the choice of the card with a factor of $0.29(29 \%)$. It means consumers are aware of the value of the card industry standards. Therefore, it helps in choosing the next card option.

\section{Conclusion}

The avid reader aware of the study was intended to find the reasons that contribute to one's decision to choose a particular payment card brand as their electronic fund transfer method. The findings also shed light on the policy decision making of introducing a local payment card. As it is identified in the analysis, the significant variables are Option, Dispute Management, and Card Industry Standards. For a national payment card scheme, in order to compete with the existing market players, dispute management plays a significant role. On average, the increase of dispute management has declined the possibility of choosing a payment card by $29 \%$. Hence, a national payment card by focusing on dispute management can establish a good competitive environment with the other payment card schemes. When it comes to adherence to the card industry standards, the possibility of choosing a payment card is increased by $29 \%$. Hence, it creates an additional opportunity for a national payment card by following the best practice of card industry standards which will establish a niche market. Also, as the Option variable explains, there 
is a $58 \%$ tendency towards not to choose a new payment card moving away from the existing card. It is a barrier to the market penetration of the new payment card scheme. In order to overcome this hurdle, the decision-makers of launching a new payment card scheme should focus on the better management of disputes and adherence to the card industry standards.

\section{References}

Allen, M. ed., (2017). The SAGE encyclopedia of communication research methods. Sage Publications.

Borzekowski, R., Elizabeth, K.K. and Shaista, A. (2008). Consumers' use of debit cards: patterns, preferences, and price response. Journal of money, credit and banking, 40(1), pp.149-172.

Brainard, L. (2017). Where Do Banks Fit in the Fintech Stack?: a speech at the Northwestern Kellogg Public-Private Interface Conference on" New Developments in Consumer Finance: Research \& Practice", April 28, 2017 (No. 950). Board of Governors of the Federal Reserve System (US).

Brown, G. and Patterson, N. (2012). Professional project dissertation, Harlow, Great Britain, Pearson.

Carten, M., Littman, D., Schuh, S.D. and Stavins, J. (2007). Consumer behavior and payment choice: 2006 conference summary. FRB of Boston Public Policy Discussion Paper, $(07-4)$.

Chatterjee, P. and Rose, R. L. (2012). Do payment mechanisms change the way consumers perceive products?. Journal of Consumer Research, 38(6), pp.1129-1139.

Churchill Jr, G.A. and Surprenant, C. (1982). An investigation into the determinants of customer satisfaction. Journal of marketing research, 19(4), pp.491-504. 
Doyle, M.A. (2018). Consumer Credit Card Choice: Costs, Benefits and Behavioural Biases (No. rdp2018-11). Reserve Bank of Australia.

Fusaro, M.A. (2013). Why do people use debit cards: evidence from checking accounts. Economic Inquiry, 51(4), pp.1986-2001.

Green, P.E. and Srinivasan, V. (1978). Conjoint analysis in consumer research: issues and outlook. Journal of consumer research, 5(2), pp.103-123.

Hatton National Bank. (2018). Dispute resolution procedure on credit cards.

[Online] Available at: https://www.hnb.net/images/bank-downloads/cardcenter/dispute-resolution-procedure.pdf. [Accessed on 18th June 2019, 11.15am].

Hauser, J.R. and Rao, V.R. (2004). Conjoint analysis, related modeling, and applications. In Marketing Research and Modeling: Progress and Prospects (pp. 141-168). Springer, Boston, MA.

Hayashi, F. (2010). Payment Card Interchange Fees and Merchant Service Charges-An International Comparison. Lydian Payments Journal, 1(3), pp.6-22.

Hirschman, E.C. (1979). Differences in consumer purchase behavior by credit card payment system. Journal of Consumer Research, 6(1), pp.58-66.

Huang, Z. (2015). Is it money laundering. Journal of Money Laundering Control.

Kuzmanovic, M. (2016). The nonstandard algorithm for constructing efficient conjoint experimental designs. Yugoslav Journal of Operations Research, 18(1).

Lam, T. and Ossolinski, C. (2015). The Value of Payment Instruments: Estimating Willingness to Pay and Consumer 
Surplus. Economic Research Department, Reserve Bank of Australia.

Leeper, T., Hobolt, S., \& Tilley, J. (2020). Measuring Subgroup Preferences in Conjoint Experiments. Political Analysis, 28(2), 207-221. doi:10.1017/pan.2019.30

Magidson, J., 1985. CONJOINT: Conjoint Statistical Analysis. JMR, Journal of Marketing Research (pre-1986), 22(000002), p.221.

Mann, R.J. (2002). Credit cards and debit cards in the United States and Japan. Vand. L. Rev., 55, p.1055.

Prange, C. (2016). Preparing Business Activities in China. In Market Entry in China (pp. 217-221). Springer, Cham.

PYMNTS. (2010). Payment Card Interchange Fees and Merchant Service Charges, An International Comparison. [ONLINE] Available at: https://www.pymnts.com/businesswire/2010/payment-card-interchange-fees-and-merchantservice-charges-an-international-comparison. [Accessed on 12th June 2019, 10.55pm]

Radhakrishan, R. (1996). Debit Cards, Plastic Money, pp 47-51.

Raghavarao, D., Wiley, J.B. and Chitturi, P. (2010). Choice-based conjoint analysis: models and designs. CRC Press.

Rutherford, L. and DeVaney, S.A. (2009). Utilizing the theory of planned behavior to understand convenience use of credit cards. Journal of Financial Counseling and Planning, 20(2).

Sarika, P. and Vasantha, S. (2019). Impact of Mobile Wallets on Cashless Transaction. International Journal of Recent Technology and Engineering (IJRTE), 7(6S5).

Securitymetrics. (2016). The Importance of the PCI DSS: Why You Should Get Compliant. [ONLINE] Available at: 
https://www.securitymetrics.com/blog/importance-pci-dsswhy-you-should-get-compliant. [Accessed on 18th June 2019, $10.57 \mathrm{am}]$.

Shui, H. and Ausubel, L.M. (2004). Time inconsistency in the credit card market. In 14th Annual Utah Winter Finance Conference.

Simon, J., Smith, K. and West, T. (2010). Price incentives and consumer payment behaviour. Journal of Banking \& Finance, 34(8), pp.1759-1772.

Soman, D. (2001). Effects of payment mechanism on spending behavior: The role of rehearsal and immediacy of payments. Journal of Consumer Research, 27(4), pp.460-474.

Soman, D. (2003). The effect of payment transparency on consumption: Quasi-experiments from the field. Marketing Letters, 14(3), pp.173-183.

Thomas, M., Desai, K.K. and Seenivasan, S. (2011). How Credit Card Payments Increase Unhealthy Food Purchases: Visceral Regulation of Vices. Journal of Consumer Research, 38(1), pp 126-139.

Visa Annual Report. (2018). Annual report 2018. 1st ed. Visa inc.

Watkins, J.P. (2000). Corporate power and the evolution of consumer credit. Journal of Economic Issues, 34(4), pp.909-932.

Yang, S., Markoczy, L. and Qi, M. (2007). Unrealistic optimism in consumer credit card adoption. Journal of economic psychology, 28(2), pp.170-185. 